DIKDAS MATAPPA: Jurnal Ilmu Pendidikan Dasar

Vol, 1. No, 2. September 2018 p-ISSN: 2620-5246 dan e-ISSN: 2620-6307

Link: http://journal.stkip-andi-matappa.ac.id/index.php/dikdas

(1) This work is licensed under a Creative Commons Attribution

4.0 International License

\title{
PENGARUH KOMPETENSI KEPEMIMPINAN KEPALA SEKOLAH TERHADAP PENINGKATAN PROFESIONALISME GURU DI SDN 20 WATANG SAWITTO
}

\author{
Nasaruddin \\ PGSD UPP Bone UNM \\ Email: nassaruddin@gmail.com
}

\begin{abstract}
Abstrak.Penelitian ini bertujuan untuk mengetahui kompetensi kepemimpinan kepala sekolah, profesionalisme guru dan untuk mengetahui pengaruh kompetensi kepala sekolah terhadap peningkatan profesionalisme guru SDN 20 Watang Sawitto.Penelitian ini merupakan penelitian verifikatif dengan populasi penelitian adalah seluruh guru SDN 20 Watang Sawitto Kabupaten Pinrang sebanyak 20 orang, sehingga penelitian ini adalah penelitian populasi. Pengumpulan data dengan teknik observasi, wawancara, angket, dan dokumentasi, sedangkan teknik analisis data adalah analisis statistik deskriptif dan statistik inferensial dengan uji normalitas data, productmoment, analisis regresi linier dan uji " $t$ ". Hasil penelitian menunjukkan bahwa: (1) secara umum kompetensi kepemimpinan kepala masih SDN 20Watang Sawitto kategori cukup tinggi (55,00\%), walaupun masih perlu untuk melakukan peningkatan kompetensi kepemimpinan kepala sekolah khususnya pada prakarsa yang tinggi dan hasrat melayani bahawahn sehingga kompetensi yang dimiliki semakin tinggi nantinya akan mempengaruhi terhadap peningkatan profesionalisme guru SDN 20 Watang Sawitto Kabupaten Pinrang, (2) Guru SDN 20 Watang Sawitto Kabupaten Pinrang memiliki profesionalismeberada pada kategori cukup tinggi $(55,00 \%)$,walaupun masih ada sebagain kecil masih ada guru yang meiiki profesionalisme yang rendah, dan (3) Ada pengaruh kompetensi kepemimpinan kepala sekolah terhadap peningkatan profesionalisme guru SDN 20 Watang Sawitto Kabupaten Pinrang, artinya semakin tinggi kompetensi kepemimpinan yang dimiliki oleh kepaa sekolah akan berpengaruh positif terhadap peningkatan profesinalisme.
\end{abstract}

Kata kunci: kompetensi, kepemimpinan, profesinalismee dan guru.

\section{PENDAHULUAN}

Dalam rangka meningkatkan kualitas pendidikan, maka salah satu komponen yang sangat menentukan adalah guru, karena dialah yang berhubungan langsung dengan siswa melalui proses belajar mengajar. Guru harus memiliki berbagai kemampuan dalammelaksanakan tugas, di samping rasa tanggung- jawab dan pengabdian demi peningkatan kualitas pendidikan. Oleh karena itu, dalam kehidupan sehari-hari di sekolah selain sebagai pendidik juga sebagai pengajar.

Penguasaan berbagai kompetensi secara profesional sebagai guru tentu saja akan menunjang efektivitas pelaksanaan tugasnya dengan penuh rasa tanggung jawab. Sekolah sebagai wadah atau tempat melaksanakan berbagai aktivitas pendidikan dan pembelajaran secara organizator amat diperlukan pemimpin yang profesional sebagai supervisor, manajer, edukator, administrator, fasilitator dan motivator di sekolah.

Tugas kepala sekolah adalah mengkoordinir dan mengarahkan segala sumber daya yang ada. Beban tugas dan tanggungjawab kepala sekolah yang besar, maka dituntut kemampuan menerapkan kepemimpinan yang demokratis demi tercapainya tujuan institusional sekolah sesuai dengan apa yang di cita-citakan.

Kepala sekolah dengan kompetensi kepemimpinannya berperan yang sangat menentukan dalam membantu mengarahkan para guru demi kelancaran pelaksanaan tugasnya sehari-hari di sekolah. Oleh karena itu, kepala 
sekolah dalam menjalankan kepemimpinannya dituntut untuk memahami karakteristik bawahannya dan memahami fenomena yang terjadi di lingkungannya. Hal ini dimaksudkan untuk menciptakan hubungan kerja yang harmonis dalam upaya bersama meningkatkan kualitas pendidikan dan pembelajaran di sekolah. Wahjoetomo (1997:49) menjelaskan mengenai fungsi kepala sekolah, yaitu:

1. Menyempurnakan tugas keluarga dalam soal pendidikan.

2. Memperluas wawasan dan pengalaman anak didik melalui transfer nilai dan peradaban.

3. Wahana penyucian dan pembersihan.

Mengingat pentingnya jalur pendidikan sekolah dalam membina siswa baik dari ranah kognitif, afektif maupun psikomotor, maka seyogianya guru dituntut untuk melaksanakan tugasnya secara profesional dengan penuh rasa tanggung jawab. Dalam rangka tugas guru sebagai tenaga yang profesional, peranan kepala sekolah sebagai pemimpin dalam suatu jalur pendidikan sekolah sangat menentukan dalam mengarahkan guru-guru di sekolah.

Menurut sebagian besar guru-guru yang ada di SDN 20 Watangm Sawitto Kabupaten Pinrang bahwa kepemimpinan kepala sekolah kurang tegas sehingga akibatnya sebagian guru-guru tidak mengindahkan peraturan yang berlaku, baik itu kedisiplinan maupun tugas dalam mengajar sebagai tenaga profesional. Maka perlu adanya perhatian khusus pimpinan dalam hal ini adalah kepala sekolah.

Berdasarkan observasi di SDN 20

Watang Sawitto Kabupaten Pinrang bahwa dalam pelaksanaan tugas mengajar sebagai guru yang profesional belum terlaksana dengan baik. Masih ada beberapa guru yang belum menunjukkan rasa tanggung jawab yang tinggi dalam melaksanakan tugas sebagai tenaga yang berprofesional. Hal ini dilihat dari faktor kedisiplinan guru melaksanakan tugas yaitu datang terlambat masuk sekolah atau cepat pulang sekolah, meninggalkan sekolah pada saat proses belajar mengajar, dalam artian hanya datang mengisi absen saja. Mengenai metode belajar dan media yang digunakan bersifat monoton sehingga siswa merasa jenuh yang seharusnya menggunakan laptop sehingga memberikan warna baru dalam proses belajar mengajar.
Secara teoritis, oleh Akadum (1999:40) menyatakan ada lima penyebab rendahnya prefesionalisme guru:

1. Masih banyak guru yang tidak menekuni profesinya secara total.

2. Rentan dan rendahnya kepatuhan guru terhadap norma dan etika profesi keguruan.

3. Pengakuan terhadap ilmu pen- didikan dan keguruan masih setengah hati dan pengambilan

kebijakan dan pihak-pihak terlihat. Hal ini terbukti dari masih belum mantapnya kelembagaan pencetak tenaga keguruan dan kependidikan.

4. Masih belum Smooth-nya perbedaan pendapat tentang proporsi materi ajar yang diberikan kepada calon guru.

5. Masih belum berfungsi PGRI sebagai organisasi profesi yang berupaya secara maksimal meningkatkan profesional anggotanya.

Keterangan tersebut menjadi argumentasi mendasar untuk melakukan penelitian tentang masalah kompetensi kepemimpinan kepala sekolah terhadap peningkatan profesionalisme guru SDN 20 Watang Sawitto Kabupaten Pinrang.

Fenomena tersebut secara empiris maupun atas dasar kajian teoritis amat menarik untuk dikaji dengan penelitian ilmiah dalam upaya peningkatan profesionalisme guru yang pada akhirnya dapat meningkatkan prestasi belajar siswa. Melalui kompetensi kepemimpinan kepala sekolah diharapkan mampu mengelola secara profesional sekolah yang dipimpinnya, termasuk peningkatan profesionalisme guru yang berdampak langsung kearah peningkatan kualitas pendidikan.

Sehubungan dengan uraian di atas, maka penulis tertarik untuk mengkaji pengaruh kompetensi kepemimpinan kepala sekolah terhadap peningkatan profesionalisme guru SDN 20 Watang Sawitto Kabupaten Pinrang.

\section{HASIL PENELITIAN DAN PEMBAHASAN}

\section{Analisis Statistik Deskriptif}

Analisis statistik deskriptif dimaksudkan untuk mengetahui kompetensi kepemimpinan kepala sekolah dan profesionalisme guru SDN 20 Watang Sawitto Kabupaten Pinrang, dengan menggunakan tabel distribusi frekuensi 
dan persentase. Untuk kepentingan tersebut, maka akan dilakukan analisis secara terpisah.

a. Kompetensi Kepemimpinan Kepala Sekolah Kompetensi kepemimpinan kepala SDN 20 Watang Sawitto Kabupaten Pinrang dibagi atas empat kategori, yaitu: tinggi, cukup tinggi, rendah dan sangat rendah. Jelasnya dapat dilihat pada tabel distribusi, frekuensi dan persentase berikut.

Tabel 1. Distribusi frekuensi dan prosentase kompetensi kepemimpinan kepala SDN 20 Watang Sawitto Kabupaten Pinrang

\begin{tabular}{cccc}
\hline $\begin{array}{c}\text { Variabel } \\
\mathbf{X}\end{array}$ & Interval & $\begin{array}{c}\text { Freku } \\
\text { ensi }\end{array}$ & Presentase \\
\hline Tinggi & $47-57$ & 9 & 44,00 \\
\hline $\begin{array}{c}\text { Cukup } \\
\text { tinggi }\end{array}$ & $36-46$ & 11 & 55,00 \\
\hline Rendah & $25-35$ & 0 & 0,0 \\
\hline $\begin{array}{c}\text { Sangat } \\
\text { rendah }\end{array}$ & $14-24$ & 0 & 0,0 \\
\hline Jumlah & & 20 & 100,000 \\
\hline
\end{tabular}

Berdasarkan tabel 1, kompetensi kepemimpinan kepala sekolah yang menjawab tinggi sebanyak 9 responden atau $45,00 \%$, yang menjawab cukup juga sebanyak 11 responden atau55,00\% yang menjawab rendah dan sangat rendah tidak satupun responden.

Pada rentangan 14-57 nilai rata-rata (mean) 44,50 berada pada rentang 36-46 dengan kategori cukup tinggi dengan standar deviasi 5,03 dan point tertinggi berada di cukup tinggi.

Dapat disimpulkan bahwa kompetensi kepemimpinan kepala sekolah berada pada kategori cukup tinggi, hal ini menunjukkan bahwa kompetensi kepemimpinan yang dimiliki oleh kepala SDN 20 Watang Sawitto Kabupaten Pinrang cukup tinggi meskipun demikian masih perlu adanya peningkatan sehingga kompetensi yang dimiliki oleh kepala sekolah dapat mencapai kategori tinggi.

Hal ini dapat dilihat dari ke disiplinan kepala sekolah yang selalu tepat waktu berada di sekolah dan melaksanakan tugas dan tanggung jawabnya sebagai leader (pemimpin).

\section{b. Profesionalisme guru}

Untuk memperoleh gambaran tentang profesionalisme guru SDN 20 Watang Sawitto
Kabupaten Pinrang, maka dibagi empat kategori, yaitu: tinggi, cukup tinggi, rendah dan sangat rendah. Lebih jelasnya dapat dilihat pada tabel berikut:

Tabel 2. Distribusi frekuensi dan prosentase profesionalisme guru SDN 20 Watang Sawitto Kabupaten Pinrang

\section{Variabel Interval Frekuensi Presentase} Y

\begin{tabular}{cccc} 
Tinggi & $21-25$ & 5 & 25,00 \\
\hline $\begin{array}{c}\text { Cukup } \\
\text { tinggi }\end{array}$ & $16-20$ & 11 & 55,00 \\
\hline Rendah & $11-15$ & 4 & 20,0 \\
\hline $\begin{array}{c}\text { Sangat } \\
\text { rendah }\end{array}$ & $6-10$ & 0 & 0,0 \\
\hline Jumlah & & 20 & 100,000 \\
\hline
\end{tabular}

Berdasarkan tabel 2, profesionalisme guru dan 20 responden yang menjawab tinggi, 5 responden atau 25,00 persen, yang menjawab cukup tinggi, 11 responden atau 55,00 persen, yang menjawab rendah, 4 responden atau 20,00 persen, dan tidak ada responden yang menjawab sangat rendah.

Pada rentangan 6-25 nilai rata-rata (mean) 19,05 berada pada rentang 16-20 dengan kategori cukup tinggi dengan standar deviasi 3,19 dan point tertinggi pada kategori cukup tinggi. Hal ini dapat dilihat dari tingkat absensi pegawai, dimana pada jam kerja mereka senantiasa berada ditempat untuk mengisi absensi yang telah disediakan, bukan hanya itu kegiatan proses belajar mengajar selalu aktif (terisi) dan nilai akhir semester siswa dari tahun ke tahun selalu meningkat.

\section{Analisis Statistik Inferensial}

a. Uji Normalitas Data

Sebelum dilakukan analisis lebih lanjut, terlebih dahulu perlu diketahui apakah data penelitian ini sudah memenuhi persyaratan penggunaan statistik yang akan digunakan dalam pengujian hipotesis. Pengujian persyaratan analisis untuk penggunaan statistik korelasi adalah data yang diperoleh sekurang-kurangnya normal.

Pengujian normalitas digunakan rumus chi-square dengan kriteria telah hipotesis yang menyatakan bahwa data terdistribusi normal jika harga $\mathrm{x}^{2}$ hiung lebih kecil dari pada harga $\mathrm{x}^{2}$ tabel pada larai signifikansi $\mathrm{x}=0,05$. 
Rangkuman hasil pengujian normalitas data penelitian ditunjukan pada tabel 3 berikut ini. Rangkuman hasil pengujian normalitas data penelitian berikut ini menunjukan bahwa variabel kompetensi kepemimpinan kepala sekolah terhadap peningkatan profesionalisme guru terdistribusi normal.

Tabel 3. Hasil Uji Normalitas Data

\begin{tabular}{ccccc}
\hline Variabel & df & $\mathbf{x}^{2}{ }_{\text {hitung }}$ & $\begin{array}{c}\mathbf{x}^{2}{ }_{\text {tabel }} \\
(\mathbf{0 , 0 5})\end{array}$ & Keterangan \\
\hline $\mathrm{X}$ & 13 & 3,800 & 29,82 & Normal \\
\hline $\mathrm{Y}$ & 8 & 3,400 & 21,96 & Normal \\
\hline
\end{tabular}

b. Uji Koreasi Product Moment

Uji korelasi product moment dimaksudkan untuk mengetahui ada tidaknya hubungan kompetensi kepemimpinan kepala sekolah dan profesionalisme guru dan tingkat hubungan kedua variabel.

Berdasarkan hasil perhitungan korelasi product moment diperoleh ritung sebesar 0,947 sedangkan $\mathrm{r}_{\text {tabe }}$ pada taraf signifikan $5 \%$ diperoleh nilai sebesar 0,444 . Karena $r_{\text {hitung }}>r_{\text {tabel }}$ maka dapat dinyatakan bahwa terdapat pengaruh yang sinigfikan kompetensi kepemimpinan kepala sekolah terhadap profesonalisme guru SDN 20 Watang Sawitto Kabupaten Pinrang, dengan tingkat hubungan kedua variabel adalah sangat kuat, karena nutung yang diperoleh pada interval 0,80-1,000 (tabel interpretasi nilai r). Adapun koefisien determinan (KP) sebesar 89,7\%, ini berarti kontribusi variabel kompetensi kepemimpinan kepala sekolah terhadap profesionalisme guru di SDN 20 Watang Sawitto Kabupaten Pinrang sebesar $89,7 \%$, sedangkan sisanya sebesar $10,3 \%$ ditentukan oleh faktor-faktor yang tidak diteliti dalam penelitian ini.

\section{Analisis Regresi Linier}

Analisis regresi linier dimaksudkan untuk menguji kelinieran kedua variabel yaitu apakah nilai-nilai kedua variabel dapat membentuk suatu garis Tinier atau tidak, dan uji-F digunakanuntuk menguji hipotesis yang berbunyi "ada pengaruh signifikan kompetensi kepemimpinan kepala sekolah terhadap peningkatan profesionalisme guru SDN 20 Watang Sawitto Kabupaten Pinrang".

Untuk menganalisis persamaan garis regresi maka digunakan rumus yaitu: $\mathrm{Y}=\mathrm{a}+\mathrm{bx}$ dari hasil perhitungan diperoleh persamaan regresi yaiiu: $Y=-7,641+0,600 x$.

Hasil di atas dapat dioperasikan dengan contoh perhitungan jika misalnya $\mathrm{x}=1$ maka,

$\mathrm{y}=-7,641+0,600(1)$

$y=-7,041 \Rightarrow-7,641-(-7,041)=0,600$.

Jadi jika terdapat perubahan atau peningkatan kompetensi kepemimpinan sebesar satu poin, maka memberi pengaruh signifikan terhadap profesionalisme guru sebesar 0,600, demikian pula sebaliknya atau dapat membentuk garis linier. Ini berarti semakin tinggi kompetensi kepemimpinan maka semakin tinggi pula profesionalisme guru. Untuk hal tersebut dilakukan dengan analisis uji-F.

Berdasarkan hasil analisis SPSS 15 diperoleh nilai $F_{\text {hitung }}$ sebesar 156,440 sedangkan nilai $\mathrm{F}_{\text {tabe }}$ dengan $\mathrm{dk}=20-2$ pada taraf signifikan 5 persen, diperoleh nilai sebesar 4,14. Karena nilai $F_{\text {hitung }}$ lebih besar daripada nilai $F_{\text {tabel, }}$ maka hipotesis penelitian yaitu "ada pengaruh kompetensi kepemimpinan terhadap peningkatan profesionalisme guru SDN 20 Watang Sawitto Kabupaten Pinrang" dinyatakan diterima. Jadi semakin tinggi kompetensi kepemimpinan yang dimiliki oleh kepala sekolah akan memberi dampak positit semakin tinggi pula profesionalisme guru SDN 20 Watang Sawitto Kabupaten Pinrang.

\section{Uji t}

Hipotesis dalam penelitian ini adalah "ada pengaruh kompetensi kepemimpman kepala sekolah terhadap peningkatan profesionalisme guru SDN 20 Watang Sawitto Kabupaten Pinrang, untuk lebih jelasnya maka digunakan uji "t".

Berdasarkan perhitungan uji-t diperoleh thitung sebesar 12,508 sedangkan tabel sebesar 1,72 pada taraf signifikan 5 persen, karena $t_{\text {hitug }}>t_{\text {tabel }}$ maka sebagai konsekuensinya hipotesis penelitian dinyatakan diterima. Ha ini berarti semakin besar konstnbusi yang diberikan kompetensi kepemimpinan kepala sekolah akan semakin tinggi profesionalisme guru SDN 20 Watang Sawitto Kabupaten Pinrang.

Hasil penelitian ini menunjukkan bahwa kompetensi kepemimpinan kepala SDN 20 Watang Sawitto Kabupaten Pinrang adalah cukup tinggi, cukup tingginya kompetensi kepemimpinan kepala sekolah tersebut di tinjau dari aspek watak dan kepribadian yang terpuji, prakarsa yang tinggi, hasrat melayani bawahan, 
sadar dan paham kondisi lingkungan, intelegensi yang tinggi, berorentasi ke masa depan, sikap terbuka dan lugas, dan widyaiswara yang efektif. Dengan kompetensi yang cukup tinggi yang dimiliki kepala SDN 20 Watang Sawitto Kabupaten Pinrang memungkinkan guru-guru mampu melaksanakan tugasnya secara profesional berkat kepemimpinan yang cukup tinggi dari kepala sekolah.

Kompetensi kepemimpinan kepalas ekolah yang cukup tiggi berdampak positif terhadap peningkatan pfofesionalisme guru dalam melaksanakan tugasnya sebagai tenaga pengajar yang profesional. Cukup tingginya profesionalisme guru ditinjau dan kemampuan merencarukan pembelajaran, kemampuan melaksanakan pembelajaran, dan mampu mengevaluasi hasil belajar. Cukup tingginya profesionalisme guru dalam melaksanakan proses belajar mengajar diharapkan dapat mempengaruhi kualitas proses belajar mengajar yang mengarah pada peningkatan kualitas pendidikan.

Menurut Kepala SDN 20 Watang Sawitto Kabupaten Pinrang untuk meningkatkan profesionalisme guru, maka upaya yang dilakukan adalah meningkatkan kedisiplinan, menambah wawasan guru melalui pelatihan-pelatihan, melaksanakan proses belajar mengajar sesuai dengan kurikulum, dan menganjurkan kepada guru-guru untuk mengikuti seminar-seminar yang dilaksanakan oleh pemerhati pendidikan, sedangkan menurut guru SDN 20 Watang Sawitto Kabupaten Pinrang adalah menyusun rencana 5 tahun kedepan, melaksanakan lokakarya untuk penyusunan KTSP, dan penempatan posisi jabatan sesuai dengan keahliannya.

Adanya Keterkaitan antara kompetensi kepemimpinan kepala sekolah terhadap peningkatan profesionalisme guru SDN 20 Watang Sawitto Kabupaten Pinrang diperkuat dan diterimanya hipotesis penelitian ini yang menunjukkan adanya hubungan yang signifikan antara kompetensi kepemimpinan kepala sekolah terhadap peningkatan profesionalisme guru SDN 20 Watang Sawitto Kabupaten Pinrang.

Hasil penelitian tersebut relevan dengan tugas dan fungsi kepala sekolah Depdiknas (2000) antara lain: Sebagai manajer yang merencanakan, mengorganisasikan, memimpin, dan mengendalikan anggota-anggota organisasi serta mendayagunakan seluruh sumber daya dalam rangka mencapai tujuan yang telah ditetapkan.

Berdasarkan hal tersebut, maka dapat dinyatakan bahwa tinggi rendahnya profesionalisme guru dalam melaksanakan proses belajar mengajar sangat ditentukan oleh faktor tinggi rendahnya kompetensi kepemimpinan yang dimiliki oleh seorang kepala sekolah. Oleh karena itu, seorang kepala sekolah seyogyanya selalu mengembangkan kompetensi kepemimpinannya sehingga mampu menggerakkan atau memberdayakan segala potensi yangdimiliki sekolah.

\section{SIMPULAN DAN SARAN}

Berdasarkan hasil penelitian, maka disimpulkan sebagai berikut

1. Secara umum kompetensi kepemimpinan kepala SDN 20 Watang Sawitto Kabupaten Pinrang sudah cukup tinggi, walaupun masih perlu untuk melakukan peningkatan kompetensi kepemimpinan kepala sekolah khususnya pada prakarsa yang tinggi dan hasrat melayani bawahan sehingga kompetensi yang dimiliki semakin tinggi yang nantinya akan mempengaruhi terhadap peningkatan profesionalisme guru SDN 20 Watang Sawitto Kabupaten Pinrang.

2. Secara umum pegawai atau guru SDN 20 Watang Sawitto Kabupaten Pinrang memiliki profesionalisme yang cukup tinggi walaupun masih ada sebagian kecil masih ada guru yang memiliki profesionalisme yang rendah.

3. Ada pengaruh kompetensi kepemimpinan kepala sekolah terhadap peningkatan profesionalisme guru SDN 20 Watang Sawitto Kabupaten Pinrang, artinya semakin tinggi kompetensi kepemimpinan yang dimiliki oleh kepala sekolah akan berpengaruh positif terhadap peningkatan profesionalisme guru SDN 20 Watang Sawitto Kabupaten Pinrang.

Berdasarkan kesimpulan di alas, maka diajukan saran-saran kepada:

1. Kepala SDN 20 Watang Sawitto Kabupaten Pinrang, hendaknya melakukan pengembangan kompetensi kepemimpinannya demi peningkatan sekolah yang dipimpinnya.

2. Para guru SDN 20 Watang Sawitto Kabupaten Pinrang, hendaknya menambah wawasan melalui pelatihan, mengikuti 
seminar sehingga profesionalisme yang dimiliki semakin meningkat.

3. Adanya pengaruh positif kompetensi kepemimpinan kepala sekolah terhadap peningkatan profesionalisme guru, maka seyogyanya pihak sekolah atau instansi yang terkait harus menaruh perhatian, hal tersebut demi perkembangan masa yang akan datang berdampak pada generasi muda dalam hal ini adalah siswa.

\section{DAFTAR RUJUKAN}

Akadum. 1999. Potret Guru Memasuki Millennium Ketiga, Suatu Pembaharuan, (Online) (http://www.Suatu Pembaharuan.Com/news/1999/01/2.019 9/OpEd diakses 30 Mei 2008).

Arikunto, Suharsimi. 1993. Prosedur Penelitian Suatu Pendekatan Praktik. Jakarta.:Bina Aksara.

Daryanto. 2005. Administrasi Pendidikan.Jakarta: PT. Rineka Cipta.

Depdikbud. 1994. Petunjuk Pelaksanaan Administrasi Pendidikan di Sekolah. Jakarta: Depdikbud.

2003. Kamus Besar Bahasa Indonesia. Edisi Ketiga. Jakarta: Balai Pustaka.

Depdiknas. 2000. Kumpulan Materi Pelatihan Metode Material Refetif dan Manajemen. Jakarta: Dirjen Pendidikan Dasar dan Manajemen.

DirayantiMudjiono. 1999. Belajar dan Pebelajaran. Jakarta: Rineka Cipta

Hadi, Sutrisno. 2000. Statistik jilid 1. Yogyakarta: Andi.

Hamalik, Oemar. 2004. Belajar Mengajar. Jakarta: Bumi Aksara.

Handayaningrat, Soewarno. 1993. Pengantar Ilmu Studi Administrasi dan Manajemen . Jakarta: CV. Dirjen Masagung.

Hessel Bein, F. dkk. 1997. Organisasi Masa Depan (alih bahasa: Achmad Kemal). Jakarta: Gramedia.

Ibrahim \& Syaohid, Nana, 2003. Perencanaan Pengajaran. Jakarta: Rineka Cipta.

Kartono, Kartini. 1992. Pemimpin dan Kepemiminan Apakah Pemimpin Informasi itu. Jakarta: PT. Raja Grafindo.

Mulyasa. 2004. Kurikulum Berbasis Kompetensi. Bandung: PT. Remaja Rosdakarya. Nawawi,
Hadari. 1997. Administrasi Pendidikan. Jakarta: PT Toko Gunung Agung.

Pidarta. 1999. Pemikiran Tentang Supervisi Pendidikan. Jakarta: Bumi Aksara.

Purwanto, Ngalim. M. 1996. Administrasi dan Supervisi Pendidikan. Bandung: PT. Remaja Rosdakarya.

Rifai, 1982. Administrasi dan Supervisi Pendidikan $l$ (Bagian Administrasi Pendidikan). Bandung: Jemmers.

Saherrian Piet A, Akida Sahertian. 1990. Supervisi Pendidikan Dalam Rangka Porgam Inservice Education. Jakarta: Rineka Cipta

Siswanto, Bedjo. 1990. Manajemen Modern. Bandung: Sinar Baru.

Slamelo. 2003. Belajar dan Faktor-Faktor Yang Mempengaruhinya. Jakarta: Rineka Cipta.

Sudjana, 1996. Metode Statistika. Bandung

Tarsito. 2004. Dasar-dasar Proses Belajar Mengajar. Bandung: Sinar dalam

Algensindo, Sugiyono. 2002. Metode Penelitian Administrasi. Bandung: Alfabeta.

Syah, Mahibbin. 2003. Psikologi Pendidikan dengan Pendekatan Baru. Bandung: PT. Remaja Rosdakarya

Syamsi, Ibnu. 1994. Pokok-Pokok Organisasi dan Manajemen. Jakarta: PT. Rineka Cipta.

Thoha, Miftah. 2000. Perilaku Organisasi (konsep dasar dan aplikasinya). Jakarta: Raja Grafindo Persada.

Trihendradi, Conelius. 2005. SPSS 12 Statistik Inferen Teori Dasar \& Aplikasinya. Yogyakarta: Andi.

Usman, M. Uzer. 2003. Menjadi Guru Profesional. Bandung: PT. Remaja Rosdakarya.

Wahjoetomo. 1997. Perguruan Tinggi Pesantren, Pendidikan Alternatif Masa Depan. Jakarta: Gema Insani Press. 